\title{
Interreligious Dialogue Groups Enabling Human Agency
}

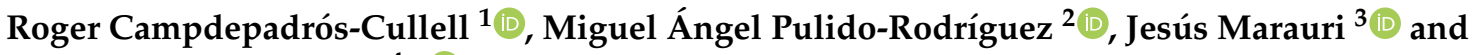 \\ Sandra Racionero-Plaza $4, *$ (D)
}

1 Department of Business Studies, Sociology Unit, University of Girona, 17003 Girona, Spain; roger.campdepadros@udg.edu

2 Department of Social Education and Social Work, Faculty of Social Education and Social Work Pere Tarres, Ramon Llull University, 08021 Barcelona, Spain; mapulido@peretarres.url.edu

3 Department of Educational Innovation and Organization, University of Deusto, 48007 Bilbo, Spain; jmarauri@deusto.es

4 Department of Sociology, University of Barcelona, 08007 Barcelona, Spain

* Correspondence: sandraracionero@ub.edu

Citation: Campdepadrós-Cullell,

Roger, Miguel Ángel

Pulido-Rodríguez, Jesús Marauri, and

Sandra Racionero-Plaza. 2021.

Interreligious Dialogue Groups

Enabling Human Agency. Religions

12: 189. https://doi.org/10.3390/

rel12030189

Academic Editor: Svetlana Sharonova

Received: 13 February 2021

Accepted: 8 March 2021

Published: 12 March 2021

Publisher's Note: MDPI stays neutral with regard to jurisdictional claims in published maps and institutional affiliations.

Copyright: (c) 2021 by the authors. Licensee MDPI, Basel, Switzerland. This article is an open access article distributed under the terms and conditions of the Creative Commons Attribution (CC BY) license (https:/ / creativecommons.org/licenses/by/ $4.0 /)$.
Abstract: Evidence has shown that interreligious dialogue is one of the paths to build bridges among diverse cultural and religious communities that otherwise would be in conflict. Some literature reflects, from a normative standpoint, on how interreligious dialogue should be authentic and meaningful. However, there is scarce literature on what conditions contribute to this dialogue achieving its desirable goals. Thus, our aim was to examine such conditions and provide evidence of how interreligious dialogue enables human agency. By analyzing the activity of interreligious dialogue groups, we document the human agency they generate, and we gather evidence about the features of the conditions. For this purpose, we studied four interreligious dialogue groups, all affiliated with the United Nations Educational, Scientific and Cultural Organization's (UNESCO) Association for Interreligious Dialogue (AUDIR), employing in-depth interviews and discussion groups. In these groups, which operate in diverse and multicultural neighborhoods, local actors and neighbors hold dialogues about diversity issues. In so doing, social coexistence, friendship ties, and advocacy initiatives arise. After analyzing the collected data, we conclude that for interreligious dialogue to result in positive and promising outputs, it must meet some principles of dialogic learning, namely equality of differences, egalitarian dialogue, cultural intelligence, solidarity, and transformation.

Keywords: interreligious dialogue; human agency; conditions; principles; dialogic learning; egalitarian dialogue; equality of differences; solidarity; transformation

\section{Introduction}

Attacking foreigners, immigrants, and others who are different is still widespread in Europe today (Duina and Dylan 2020), where practitioners of religions that are considered different face notable exclusion and incomprehension. Some authors have stated that, contrary to some predictions regarding modernity's process of secularization, religion has not diminished but rather increased in importance, as most of the world's population is religious (Knitter 2013, p. 140; Küng [1990] 1992). Additionally, as a simple empirical observation elucidates, modernity has not meant less religion or the extinction of religious beliefs but the equality of all beliefs (Berger 2014), resulting in a contemporary secular public sphere in multicultural contexts that has become a habitat for interfaith dialogue (Hedges 2019), as multicultural laicism proposes (De Botton and Pulido-Rodríguez 2013). Therefore, the social integration of religious diversity is an issue that must be addressed by today's societies if they want to be cohesive.

Interreligious dialogue has been underlined, among other pedagogical or social actions, as an effective tool to achieve social progress such as social coexistence, mutual understanding, knowing the other, and reducing prejudices (Torradeflot 2002). Küng 
([1990] 1992) states that such dialogue is the only way to achieve these outcomes in a multireligious world. The last three decades have witnessed a flourishing of social actors, religious groups, institutions, representatives, and governments launching different interreligious dialogue initiatives. They have, however, achieved entirely different results (Swidler 2013). This article summarizes research that aimed to examine what interreligious dialogue initiatives have shown success in achieving social goods and what conditions are associated with their success. Some literature explores the benefits of interreligious dialogue, while other articles document interreligious dialogue practices that achieve desirable goals. None of them, however, conducts an in-depth analysis of the factors that lead to the success of interreligious dialogue. To fill this gap, we address the following hypothesis: implementing certain principles and conditions such as egalitarian dialogue, equality of differences, cultural intelligence, and solidarity in interreligious dialogue groups allows and enables interreligious dialogue to promote human agency. Moreover, by interviewing four interreligious dialogue groups that guide their practices according to these conditions, we show that they enable human agency as well as personal and social transformations; for instance, participants gain self-confidence and self-acceptance and their own beliefs, convictions, and thoughts are strengthened, leading to increased mutual understanding, improved coexistence between groups, and reduced fears, prejudices, intolerance, discrimination, and exclusion.

Giddens ([1987] 1990, p. 16) describes human agency as the process by means of which this agency acts to produce, reproduce and change structures (... ); because on the notion of agency lies the capacity to change the social universe, consequently avoiding those scientific laws that describe that universe. We focused on the production of human agency because some of the current European structures and policies have not succeeded in achieving social integration or in improving the social coexistence of diversity (Wieviorka 2007; Flecha 1999; Touraine 1997; Taylor et al. [1992] 2003), so they need to be challenged and changed. Additionally, we endorse a dual perspective (Giddens [1984] 2003; Habermas [1981] 2010) that analyzes, on the one hand, the systems and structures over which social action and social issues stand and, on the other hand, human competences such as understanding, judging, speaking, and acting through which human agents can play an essential role in maintaining, defining, and constructing both structures and social actions. Some evidence shows that most of the ideas and energy for changing structures are bottom-up, from individuals and civil society organizing to address issues in their daily lives that later translate into public policies (Aiello et al. 2021). Drawing from this observation, we will contribute to social impact research that provides citizenship and policy designers with the knowledge to transform and improve their reality (Torras-Gómez et al. 2019).

\section{Literature Review}

In this section, we will first review the definition, historicity, and main features of interreligious dialogue. Second, we will briefly consider what conditions lead to interreligious dialogue conflict or misunderstanding. Last, we will examine those theories and documented experiences that identify the conditions that enable interreligious dialogue to improve the lives of participants and citizens. We have reviewed diverse disciplinary sources that reflect religion's multidisciplinary nature (Küng [1990] 1992, p. 160).

According to several authors, even if there have been isolated cases or experiences of interreligious dialogue in history, such as Ashoka the Great, Saint Francis of Assisi, or Akbar the Great (Sen [2005] 2007, p. 42), their impacts were sometimes partial, instrumental, personality-dependent, and geographically limited, and had little continuity (Swidler 2013; Moin 2017). Some authors point to the crucial shift with eighteenth- and nineteenthcentury enlightenment, which puts freedom and rationality at the heart of the human experience (Swidler 2013, p. 4) and signifies the beginning of the deabsolutization, dynamization and dialogization of the truth (ibid., p. 11).

Within the Catholic Church, the real interreligious impulse arose during the Second Vatican Council between 1962 and 1965. Before this, the famous phrase extra Ecclesiam 
nulla salus had been present in the Church since its beginnings. Within the Second Vatican Council, several documents were to be forerunners of dialogue, relatively equal to what has been established in other churches. The first was a pastoral, not dogmatic, constitution on the position and commitment of the Church to the betterment of the world (Gaudium et Spes 1965). Two other decrees promoted this openness towards other Christian religions: the decree on the relationship of the Roman Church with the Eastern Catholic Churches (Orientalium Ecclesiarum 1964) and the decree on ecumenism, i.e., a dialogue among Christian churches (Unitatis Redintegratio 1964). Third, within the declarations, it is relevant to refer to the one that develops the idea of religious freedom, which recognizes the right of every person to seek spirituality (Dignitatis Humanae 1965) and to the declaration of non-Christian religions, which recognizes the value of other religious beliefs that help people in their personal and social development (Nostra Aetate 1965). Furthermore, based on the Council's reflections, Pope Paul VI created in 1964 the Secretariat for Non-Christians, which would be the precursor of the current Pontifical Council for Interreligious Dialogue (Pastor Bonus 1988) created by John Paul II. This dicastery seeks to foster dialogue with other religions that shows people's spiritual sensitivity.

Twentieth-century history has witnessed multiple reflections through which religious individuals and institutions stopped considering themselves the ultimate truth and started recognizing that truth may have different expressions and forms. Among these, there is the World Council of Churches founded in 1948 and the non-governmental organization (NGO) Religions for Peace founded in 1970; recent decades have also witnessed Islamic communities and representatives massively endorsing interreligious dialogue, as is the case of the KAICIID Dialogue Centre founded in 2012 (Khan et al. 2020; Swidler 2013, p. 9).

Institutions and academics depict different types of interreligious dialogue pursuing or achieving different kinds of goals or outputs. Most of them endorse the Vatican Pontifical Council for Interreligious Dialogue (VPCID) classification of the dialogue of life, the dialogue of action, the dialogue of theological exchange, and the dialogue of religious experience. According to Mortensen (2002), altogether, this dialogue will seek to embrace truth (which involves science) and wisdom (which includes the various religious traditions) in the reciprocal interaction that is marked by love (p. 63).

Likewise, interreligious dialogue can take multiple performative forms; we can find it in the daily interactions between neighbors, in formal discussions, in debates or conferences organized by private, civil society, or public institutions, where academics, experts or religious representatives participate, in dialogue groups' encounters with citizen and religious representatives participation, or around social activism linked to social issues such as poverty alleviation, housing, or education (Cornille 2013a, p. xii). Among its goals are improving the coexistence between different congregation communities, pursuing certain personal and social transformations or social change, knowing others, and achieving personal or collective religious growth (Cornille 2013a, p. xii). For some authors, the goal of interreligious dialogue is particularly about achieving mutual understanding (Panikkar 1999, p. 10), while for others, it is above all about reaching a real pacification between religions and the world (Küng [1990] 1992, p. 161).

There are still some factors that lead to clashes between communities. We can call them exclusory factors, such as barriers to dialogue, systemic walls, social inertia, the weight of colonial history, and distorted images of certain cultures and religions built by university departments to support or legitimize colonial policies (Said [1978] 2002). These factors reach our days through media, films, journals, and novels (Abu-Lughod 2013) and spread through online social networks with little opposition, which probably amplifies their distortion. Notwithstanding, there are increasing theorizations and practices that will eventually tear down the walls mentioned before.

Several authors have reflected on the conditions that allow interreligious dialogue to take place. Freire identifies three conditions: love, hope, and orientation towards praxis and action (Freire [1968] 1995). Knitter (2013, pp. 144-46) speaks about compassion, conversion, collaboration, comprehension, and communion. At the same time, Cornille 
(2013b, p. 21) refers to epistemological humility, commitment, interconnection, empathy, and hospitality. For (Knauth and Dörthe 2019), interpersonality, a reference to meaning, and multiperspectivity describe the mode in which religion becomes significant for dialogical processes. Flecha's ([1997] 2000) Dialogic Learning theory, building upon and going beyond very diverse theories, poses various principles for genuine transformative dialogue to occur, among which we highlight equality of differences, egalitarian dialogue, cultural intelligence, solidarity, and transformation. In this paper, we assume this theory and these principles, and in what follows, we revise the contributions related to each of these five principles that are relevant to understanding effective interreligious dialogue.

For equality of differences, as Küng states, each religion must recognize itself in its portrait because there is no abstract or neutral collection of values and norms against which to measure or judge a particular religion; yet each religion expresses, tells, and talks with its values and metaphors. Therefore, a condition is the need to respect and recognize how each religion expresses and explains its values and norms (Küng [1990] 1992, pp. 135-36; Avci 2018, p. 12; Acosta 2017). Cornille (2013b, p. 29) refers to hospitality and speaks about how the reality of differences-in-similarity allows learning from the other's tradition, providing the context and the proper interpretation, avoiding rejecting others' traditions, and making them compatible with one's own, which leaves room for recognizing the truth in the others' teachings and for real growth through learning from the other. We can find this very same idea in the equal right among differences (Taylor et al. [1992] 2003), the unity in diversity (Freire [1995] 1997), or the equality of differences (Flecha [1997] 2000). Habermas ([1981] 2010) also defends the existence of universal communication structures that find different cultural expressions. In Nostra Aetate (1965), representing the position of the Vatican and the Catholic Church, Pope Paul VI also speaks of, and recognizes, unity in diversity in a particular vein. The declaration posits that all people conform to a unique community, a shared humankind, and recognizes that people have diverse religions that try to answer common and shared questions and universal concerns.

Another condition is egalitarian dialogue. Habermas expresses that there is no methodological hierarchy in a dialogue between participants within the process of social sciences' comprehension using communicative action (Habermas [1981] 2010, p. 145). The value of a statement depends on the validity claim and the evidence that supports it, not on the speaker's power position. Moreover, Habermas considers that all humans are capable of language and action and Flecha's principle of cultural intelligence (Flecha [1997] 2000) equals all individuals. Cultural intelligence encompasses academic and practical intelligence and implies an interaction where subjects hold a verbal and nonverbal relation to reach cognitive, ethic, aesthetic, and affective agreements (Flecha [1997] 2000, p. 21). Acknowledging that human words are imperfect to express divinity leads to the possibility that one may learn from the other, which moves religious traditions from self-sufficiency to openness to the other (Cornille 2013b, p. 20).

Conversely, placing oneself over the other is the opposite of humility, and this is the mistake of the religious views of absolutists or atheists when denying God's existence, for instance. As Mortensen states, the religious traditions also have their truth claims, but often the proof for these claims has to be of a different kind and may refer to ways of gaining knowledge that are not (yet?) available for the scientific method, and that should have to be recognized reciprocally by the scientific community (Mortensen 2002, pp. 81-82). Thus, for critical and egalitarian dialogue, no religion must suppose that its truth is absolute or superior to others: however, by the same token, we cannot uncritically accept every value and norm without assessing and verifying it (Küng et al. 1987, p. 15).

Regarding the principle of transformation, several theologists consider that interreligious dialogue potentially implies learning other ways of reaching transcendence or truth that is complementary to one's own (Hustwit 2016) or knowing new ways of performing and experiencing similar religious ideas (Cornille 2013b). This listening and learning imply a personal transformation through which individuals rediscover their religion or approach new forms of religiosity, i.e., interreligious and transreligious theologies, respectively 
(Hustwit 2016). Küng ([1990] 1992, p. 157) also considers that interreligious dialogue consists of a willingness to learn new ways of knowing, which implies transformation: beyond knowledge and debate, is necessarily searching a transformation, a religious understanding and a collaboration. Michaelides (2009) links interreligious dialogue to cultural and religious transformation as well. Moreover, according to Freire's theory of dialogical action, dialogue takes place collectively and entails personal and social transformations, nobody can say the true word alone (... ), saying the word referred to the world to be transformed implies the encounter of men and women to carry out that transformation (1970, pp. 103-5). Flecha's dialogic learning theory grounds research that shows that dialogic learning transforms the relations between people and their environment and even the person herself (Flecha [1997] 2000, p. 28).

Finally, there is the condition of solidarity that coincides considerably with Cornille's empathy. It is the capacity to put oneself in the other's place, to imagine or reproduce the feelings experienced in the other's situation, and even to act on the other's behalf when there is no personal material gain: This may suggest that one's actual religious beliefs and practices also play a role in the process of comprehending the religious life of the other. (...) As such, one's religious tradition plays a constitutive role in interreligious empathy (Cornille 2013b, p. 27). In contrast, other authors (Knitter 2013; Cherian 2019, p. 109) explain that solidarity leads to participation in social actions together with the different other, and that once there, it is easier for them to reach agreements on practical issues than on hermeneutical debates about the meaning of the Holy Scriptures.

The reviewed literature coincides with the relevance of principles such as equality of differences, egalitarian dialogue, cultural intelligence, solidarity, and transformation to positively impact human agency. Although empirical research has examined the benefits of interreligious dialogue groups (Azdajic 2019; Gramstrup 2017; Todd et al. 2015; Burgués et al. 2016; Mondéjar and Villarejo 2017; Cerchiaro 2019; Ubani 2018; Knitter 2013), the creation of human agency has remained almost unexplored. There is scarce literature and evidence on how and why the implementation of such principles is needed. Our research aims to address such a gap. Our research, framed in the field of studies of interreligious studies (Gustafson 2020), focuses on how these conditions developed in dialogic groups of interreligious dialogue, placing a particular emphasis on analyzing social interactions within and between groups and how they ultimately enable human agency.

\section{Materials and Methods}

This study used the communicative methodology of research. Some researchers contribute to the dialogue with the most novel and contrasting scientific knowledge in the field, whereas the individuals under research contribute with their experience and practical knowledge. This methodology allows contributions of in-depth, objective, and nonbiased knowledge about the reality of how government and society can promote social transformation that can eventually improve lives (Flecha 2014). The European Commission recognizes this methodology's relevance because research conducted in the framework program has achieved crucial social impact (Sordé Martí et al. 2020).

To carry out the research, we first conducted a literature review that involved revising articles extracted from the Social Sciences Citation Index and the Emergent Sources Citation Index from Web of Science. The search crossed the keyword "interreligious dialogue" with words or expressions such as "human agency", "social transformation", "social integration", "social cohesion", "peace", "coexistence", "premises", "conditions", "dialogue from below", "social impact", "ecumenism", and "praxis". From 110 articles initially found, we finally selected and reviewed those that most directly discussed the issues under study, which involved more than 40 references. In addition, we reviewed grey literature and institutional documents, including some confessional declarations. We reviewed any discipline related to the object of research, given that according to Küng ([1990] 1992, p. 160), we consider that the nature or characteristics of religious phenomena demand a multidisciplinary approach, which includes both contributions from the social sciences 
and theology. The diverse backgrounds of the team that conducted the research also reflect this interdisciplinarity.

In recent years, we have found that experiences of interreligious dialogue and $\mathrm{mi}-$ grants' social integration are both top-down driven, from governments' and religious institutions' initiatives, and bottom-up driven, from associations or citizenship initiatives, with the latter showing more social impact and social transformation capacity than the former (Duemmler and Nagel 2013; Mezzetti and Ricucci 2019). Thus, a selection criterion was bottom-up interreligious dialogue groups, such as AUDIR's groups. AUDIR is a secular NGO founded in Catalonia (Spain) by progressive Catholic intellectuals, independent from Catholic hierarchies and diocesan structures, which has fostered its grassroots interfaith feature and has made it more open to religious minorities and others' beliefs, such as agnostics and atheists (Astor et al. 2019). This NGO is dedicated to providing minorities with social services, defending their rights, and facilitating their religious practices.

The fieldwork consisted of interviewing conductors of three interreligious dialogue groups (groups coded as IIDG1, IIDG2, and IIDG3) and performing a communicative discussion group (DG) with another group (group coded as DGIDG4). The main selection criterion was the social impact (Reale et al. 2018) of groups on the participants, their respective communities, and the neighborhoods where they frequently interact. Two interreligious dialogue groups belong to a large metropolitan area, and the other two belong to medium-sized cities. The four of them belong to highly multireligious and multicultural environments. We conducted three in-depth communicative interviews (one per group in each of the three groups) and one communicative DG in another interreligious dialogue group. We analyzed the data according to the communicative methodology, which means identifying factors that facilitate the conditions for interreligious dialogue that foster human agency as well as those factors that constitute barriers to such outcomes.

\section{Results}

The four interviewed interreligious dialogue groups belong to the UNESCO Association for Interreligious Dialogue (AUDIR), which endorses UNESCO's Culture of Peace and the United Religions Initiative (URI) principles, which can be found on their webpage (Associació UNESCO per al Diàleg Inter-Religiós AUDIR; United Religions Initiative URI). They include dialogue, listening, respecting others' differences, religious beliefs and convictions, humbleness, being welcoming, and sincere effort. At the same time, CREA's interreligious dialogue groups (IDG) follows the deeply established principles of dialogic learning (Flecha [1997] 2000), such as egalitarian dialogue, equality of differences, solidarity, transformation, instrumental dimension (Lopez de Aguileta 2019), creation of meaning, and cultural intelligence.

The data analysis has provided insights into the conditions that enhance interreligious dialogue along the lines of enhancing human agency. Those conditions are equality of differences, egalitarian dialogue, cultural intelligence, willingness to transform, and solidarity. Under these conditions and principles, the interreligious dialogue in the analyzed groups achieved some degree of personal and social transformation, namely participants gaining human agency (self-confidence, self-acceptance, personal transformation); strengthening their own beliefs, convictions and thoughts; increasing mutual understanding; improving coexistence between groups; and reducing fears, prejudices, intolerance, discrimination, and exclusion.

\subsection{Conditions for an Interreligious Dialogue That Generates Human Agency}

First, we present the conditions or principles found in the fieldwork. The first is equality of differences-respecting the other person's religious beliefs or convictions. The four interviewed IDGs highlighted this condition, which refers to not trying to convince or convert the other to one's religion or thinking. It is relevant because one of the questions that individuals fear most is joining a group whose members may try to change their minds or beliefs. Additionally, religious institutions tend to not allow parishioners attend IDGs 
because they think they might eventually weaken their faith or raise doubts about their convictions. A frequent reaction to having one's faith and beliefs challenged is to seek to avoid repeating such an experience.

In this case, a so old-fashioned and conservative Catholic priest made an offensive and inappropriate comment about the Muslims. The chances of constituting a group ended there. At that precise moment, those attendees thought that the interreligious dialogue consists on sitting at a table and disrespecting the others. After that episode, the city council couldn't get anyone to return to the group. (IIDG2, pp. 343-47)

Thus, it is essential that every individual feel comfortable, listened to, respected, and never confronted when they talk, reflecting the principle of equality of differences and respect in URI's Charter. In one of the interviewee's words:

The truth is that doctrinal differences have never been a source of disagreement. (... ) In fact, everybody is so thorough (...) that when there isn't agreement one expresses surprise and interest, but not disagreement ( ... ). One knows that the other is different, and that will be irreducibly different all their lives, but this difference instead of turning it into a source of tensions, is seen with sympathy, it produces relax and mutual enrichment. (IIDG1, pp. 180-200)

The equality of differences makes it possible to find common values and goals, expressed in a different vein, beyond particular beliefs and the usually incompatible doctrines. These shared values are close to Human Rights but are not expressed in terms of Human Rights per se; instead, they are expressed in the terms and values of each religious tradition as social justice, equity, helping those most in need, helping the poorest, helping the sick, helping the elderly, education, and family.

In principle, we don't want to offend anybody but knowing the others and showing interest for them and see if we can share values. We specially insisted a lot on the shared values, because it was easily accepted by all the communities. We already knew that the different beliefs and doctrines are difficult to share, but with values is feasible. Moreover, it was a real convergence factor. Everybody felt comfortable with it. (IIDG1, pp. 107-11)

We also found in the groups the expression of the condition of egalitarian dialogue, which means that nobody is superior to the rest and statements are judged by their validity claim and not by the speaker's position. This principle allows each participant to explain how he or she sees, understands, or interprets certain aspects of life and the social reality of religion; to be respected when talking; and to be understood after speaking.

There is a kind of people that I would say that they stay because they appreciate the dialogue, but I would also say that it's because they have a certain human quality. In the sense that they don't think they are superior, in the sense of being willing to learn from the others, even if the others are intellectually or spiritually considered different. Then, someone may have low educational level but huge human quality. I remember a group where an illiterate Muslim participant ... That man every time he spoke, he taught something to the attendees. (IIDG1, pp. 218-28)

Another principle manifested in the groups studied was cultural intelligence. This is the ability to understand the other even if there are no shared linguistic and cultural codes. There is a common sense, a kind of intelligence that allows this type of understanding. This cultural intelligence and human quality allows a Muslim participant to intervene and stop an argument. Two parishioners of the same Christian congregation were harshly and irrespectively arguing, even insulting one another. Suddenly, a Muslim from Pakistan interrupted them, which de facto stopped the discussion, and said, "Listen, I am not Christian (... ). But didn't Jesus Christ say that you ought to love your enemies? I think that if you are 
faithful to Jesus Christ, you must stop the discussion and love each other ... " (IIDG1, pp. 469-75). There is a meta-understanding of what is happening in this incident that goes beyond doctrinal arguments or hidden power claims, fostered by cultural intelligence, and that is an expression of the human quality mentioned above. Cultural intelligence allowed the Pakistani participant to use the biblical quotation appropriately. For one of the interviewees, this human quality would eventually enable the transformation of an individual leading him to overcome exclusionary or even discriminatory positions.

A conservative with human quality works well. An intolerant progressive without human quality works badly. In the end, what is decisive, it's not the doctrinal orientation but the human disposition, the way of being, the capacity, the sensibility, the bonhomie. ( . . . ) Can we have a homophobic in the group? Yes, if he has certain human qualities ... , this human quality will change his perspective on homosexuality (... ) as it has happened. (IIDG1, pp. 306-13)

Another condition found for real interreligious dialogue is solidarity, which is the essence of interreligious dialogue among practitioners. Placing oneself in the other's position, which participants theoretically and conceptually do, is an unmistakable feature of interreligious dialogue that solidarity helps put into practice. We have collected multiple examples of this condition. When the extreme right went to a city to protest against immigrants, the interreligious dialogue group mobilized against that and favored the Muslim community, which was largely made up of immigrants (IIDG2, pp. 101-8). When U.S. Mormons donated to all those in need in a Spanish town, not only to the Spanish Mormons, the interviewee expressed the following: this is also an interreligious act because they aren't thinking about donating to themselves, but to the others (IIDG2, pp. 644-46). When Catholics in a town receive fresh food, they call the Muslims to jointly distribute it (IIDG2, pp. 673-76). Another illustrative example occurred when there was a clash between two communities that resulted in a murder. In response, the interreligious dialogue group of that town decided that each religious tradition-Protestants, Catholics, Muslims, Jehovah's Witnesses-would make their prayer in favor of peace and coexistence for the sake of the whole town (IIDG1, pp. 625-33).

Next, we describe an exceptional display of solidarity. On March 11, 2004, several alleged Al Qaeda-inspired terrorists blew up four trains at rush hour in Madrid, killing 193 people and wounding approximately 2000. Racist prejudices exploded throughout Spanish society, resulting in the whole Muslim community to fall under suspicion and to be singled out. In reaction, Muslims in Spain had the unfair and unpleasant duty to defend themselves of a crime they had not committed. In that context, Catholic and Muslim representatives agreed to meet at a famous municipal convent to hold a joint action for the missing and for peace. After their prayer at the mosque, the Muslim community went to join the Catholics at that convent. After several days of intensively being accused of being responsible for the attacks, the Muslim community was afraid of how the Christians would receive them. Maybe someone would publicly accuse them again? They felt frightened and ashamed. Nevertheless, they received a profound show of support. Thus, solidarity is another component of interreligious dialogue, as the interviewee asserts: that day, the attendees understood what interreligious dialogue is . . : Come to our temple because we shelter you and give you support (IIDG2, pp. 454-57). In the next section, we will describe how this moved and transformed most of the attendees.

\subsection{Interreligious Dialogue That Supports Human Agency and Personal and Social Transformation}

In the context of these principles and conditions, interreligious dialogue becomes dialogic and can foster human agency and lead to social and personal transformations. We have gathered and documented some examples of human agency creation that we next summarize.

There is a first and direct form of human agency generated by the interreligious dialogue under these conditions: gaining self-confidence and dealing with hostile or unfriendly 
conversations or environments towards religion. As some interviewees expressed, this is a result of knowledge acquisition, support for interactions, and respect towards difference and the egalitarian atmosphere in these groups (DGIDG4, pp. 207-24). Several of the participants confirmed that these interactions have not only given them the strength to speak out and say publicly that they are believers and to name their religion, but also doing so in potentially incomprehensive, ignorant, and hostile environments. In some contexts in Spain, just being a believer can provoke incomprehension or rejection, which may even be greater in the case of followers of a religious minority such as Muslim, Jews, or Evangelical Christians. Only acceptance and acknowledgement of one's creed or belief allows for a gain in self-confidence; this constitutes a personal transformation, which, when transferred to other working or social contexts, helps instill social transformation:

Now I have the strength to unveil some of my identity, that is made of a distinct matter, but that this is a very special and important one, that I am so proud of, and now I have arguments to defend it. And it has been participating in this interreligious group that has given to me this strength. (DGIDG4, pp. 351-54)

Human agency and transformation occur because they connect with the deepest part of people and the conditions mentioned above are precisely those that allow this to happen.

If we want to transform something in every sense, at every place we visit, first we must feel confident and strengthened, but also including all the voices and all the people. Then the interreligious dialogue in my opinion is taking into account people's deepest part, that is their beliefs, their worries, their motivations, that are the meaning of their lives. So, ignoring this is transforming nothing. To me these are key aspects to agency and social transformation. (DGIDG4, pp. 421-28)

We also find a form of human agency when an interreligious dialogue group becomes or acts as an advocacy group in the face of the incomprehension, attacks, and intolerance of other individuals, groups, or institutions. Several examples were reported in the interviews. The location of a mosque in a neighborhood faced fierce opposition from part of the community, instigated by a few individuals with real estate interests. The solidarity networks promoted by the interreligious dialogue group of that town led to the city's Muslim community receiving numerous expressions of support from various religious groups. From there, the attacks targeted not only the Muslim community but also the communities that defended them, making a strong case for the relevance and necessity of the mosque. Thus, both the Muslim community and the rest of the interreligious dialogue group supporting it received diverse attacks from many fronts: from setting fire to the Catholic convent's wall, to destroying a Loyola's commemorative monument, to spreading fake news about religious communities, to delaying construction permits, to presenting a proposal in the local council to ban the mosque's construction. For each attack, the interreligious dialogue group articulated a response, in a clear display of human agency and citizen empowerment, from signing a joint manifesto supporting freedom of religion and the right to have a place to worship, to achieving political support, appearing in the local press explaining the value of religious and cultural diversity, influencing public opinion, or counteracting and discrediting extreme-right parties by asking them in public in whose name were they speaking when they spoke evil of Muslims. In their opinion, the interreligious dialogue prevents attacks against religions from happening because when you know that somebody is not isolated you think twice before messing with him (... ), if you tease one of us you will bump into the rest of us (IIDG2, pp. 705-6).

Contrary to what people imagine when considering engaging in interreligious dialogue, the objective is far from converting to another religion or changing one's beliefs. Three of the interviewees highlighted that in more than 20 years of interreligious dialogue practice, they had never witnessed a conversion due to participation in the groups (IIDG1, pp. 434-39; IIDG2, pp. 280-83). Instead, participants experience a rediscovering or widening of the knowledge of one's religion, another type of goodness and personal transformation when these conditions are applied to interreligious dialogue. All the inter- 
viewees agree that the interreligious dialogue practice reinforces participants' own faith and beliefs, or it leads to rediscovering some ideas or practices in their religion that had long gone unnoticed until the moment that they observed something similar and analogous in another religious tradition.

In one of the interreligious dialogue groups ( . . ) a Muslim boy asked a Jewish a topic of his faith, and he did not know how to explain it, and then he went to the rabbi and asked him to explain it to him, and thanks to which the rabbi told him he explained what his faith was to the Muslim boy. Therefore, the dialogue group not only did not dilute his identity but helped him to deepen his own identity. So (... ) if I'm a staunch Christian and I'm going to have a dialogue with Muslims or Buddhists, their questions help me become a better Christian, they don't lead me to lose the Christian faith. (IIDG1, pp. 446-54)

I feel that from these dialogues I am internalizing others' beliefs as well, and then I notice that my Christianity, in my case because I am a Christian, is now more anarchist, is more Muslim, is more Pagan, is more Jewish, without stop being a Christian, and maybe I am even more than before. And well, it's a feeling that I have when participating in dialogic gatherings and in that interreligious dialogue based on dialogic learning. (DGIDG4, pp. 96-101)

Regarding social transformations due to implementing the conditions under study in the interreligious dialogue, we highlight developing mutual knowledge between communities, improving social coexistence, reducing prejudices, preventing radicalization, and reducing discrimination and social exclusion. These features of social transformation are sometimes difficult to analytically disentangle and often present themselves as intertwined. For example, we document several of these transformations because of the grassroots work of an IDG ruled by the principles mentioned above. In a municipality, a renowned member of the Muslim community died. He was so celebrated that the local council could not find a place big enough to gather the more than 800 parishioners who wanted to join the funeral to say their last goodbyes and pray for his soul. Aware of this, one of the local IDGs explained the situation to the rector of the neighborhood parish, who contacted the Pastoral Council, which then decided to let them use the church that had room enough for the event. The members of the Muslim community were so touched by this gesture that at the end of the ceremony they went to meet the rector and tearfully expressed their gratitude: henceforth you can ask us whatever, whatever, from now on we are brothers, whenever you need anything count on us (IIDG1, pp. 571-73). Through this interaction, the Muslims transformed themselves and understood that Christians are not the enemies of Islam, which the interviewee considers as one of the best ways to fight radicalization:

It is true that this dialogue, as it allows the communities to be inserted in the social networks of the neighborhood, is by definition a privileged tool for prevention and inclusion. That is why dialogue is not magical when it comes to prevention, but I find it difficult to do prevention within religious communities without practising interreligious dialogue. (IIDG1, pp. 532-36)

In a similar vein, in another municipality, the IDG acted in coordinated and agreedupon ways in the face of adversity from the equality of differences principle, in favor of coexistence and against violence. Thus, the measure had much more strength and impact than had it been carried out by just one religious community or from the local council.

In that municipality there was a conflict. There was an incident with some victims, and then the religious communities all decided, in the dialogue group they all decided to preach during the weekend in favor of coexistence and peace. This was a decision of the dialogue group. And all that following weekend, Protestants, Catholics, Muslims, Jehovah's Witnesses ( ... ) preached in favor of coexistence and peace, from their own faith. They also made a joint statement in favor of coexistence, and made it public. (IIDG1, pp. 625-33) 
Another impact or consequence of this type of dialogue is reducing both rational and emotional prejudices, which stems from the conditions of equality of differences, respecting the other, egalitarian dialogue, and not believing one is better or the holder of the ultimate truth; these conditions enable sitting at the same table with people who think differently, and allow realizing that any prejudice is harmful and represents a barrier to understanding the other and to coexistence. This is the case of a member of one of the IDGs, who explains how understanding these principles helped him reduce rational prejudice, allowing him to organize intrareligious dialogue groups of students with very diverse conservativeprogressive orientations at his university.

The interreligious dialogic gatherings helped me listening and understanding that any prejudice is bad. Moreover, this allowed me accompanying very diverse students' groups-Catholics, Protestants, Opus Dei, from the Neocatechumenal way, etc.- some very conservative, some very progressive, sharing spaces of mutual growth (...). People generally with a strong conviction in their faith, that could share ideas with very different people within the same religion, and this was so important for their training as social workers and social educators, and also as believers. (DGIDG4, pp. 178-94)

Undertaking the five conditions in the groups also reduces emotional prejudice, probably the most difficult to confront. If the above examples changed minds, the following changed hearts. A transformation took place in the display of solidarity towards the Muslim community during prayers for the wounded of the March 11, 2004 terrorist attacks in Madrid that we started to explain above. There were so many people who they did not fit inside the convent that they had to meet in the square in front of it, where the two communities met one another. The Muslims' faces were severe, staring at the ground. However, then the prioress said Let's give each other the peace as a sign of communion, and everybody progressively started hugging and shaking each other's hands. Suddenly, the grave faces became relieved expressions. The interviewee calls it "the spirit of" the convent:

Sister Mercy [a fictional name], after doing the typical parliament ( . . ) says "let's give each other the Peace as a sign of communion", ( . . . ) everyone started doing it. It was like changing the energy overnight. I call it "the spirit of" this convent. It changed like overnight. Suddenly we all went from being like "Oh my God, what an awful situation" to "Wow, it's incredibly beautiful", everyone shaking hands, everyone smiling, everyone cheering. Their faces changed completely. In other words, it was like us telling them "don't worry", "doesn't matter", "we are all together", "we support you", I don't know how to explain it, it was like a sign of support. It was amazing. It's hard to explain, is something you have to live to understand it (...). I saw a change of attitude in everyone who was there that was amazing. And this had an impact on things and activities that we later carried out. (IIDG2, pp. 439-57)

Here, we can witness personal and social transformation. First, Muslims stopped feeling rejected and guilty because of the spreading of unfair prejudices that accused them and blamed them. They also felt supported, and legitimized, to stop assuming being labelled this way. The intangible force that polarizes a society started fading away. We can untangle rational prejudices with arguments, which is necessary, but as IIGD1 highlights in the next quotation, to untangle emotional prejudices, actions are often needed. In his opinion, this is what happened after the episode mentioned above of the Catholic Pastoral Council, allowing the Muslim community to use their church to celebrate a burial.

The church was offered to the Muslim community, some images were covered, and the ceremony was held inside the church, inside the parish. Then, at the end of the ceremony, the Muslim community went to meet the rector, and with tears in their eyes thanked him, and said, "henceforth you can ask us whatever, whatever, from now on we are brothers, whenever you need anything count on us". The Muslim community, huh. This is a clear example, which is not 
just conceptual or a discourse, it reaches the heart. It is qualitative. Therefore motivational. And thus, very efficient in terms of social cohesion. There are no real words to say this, but behavioural changes occur as a result of it. And from then on, communication was smooth. I think there is still. We can say that 800 people in the Muslim community were made to think that Christians were no longer enemies of Islam. Tell me a more efficient way to fight radicalization. (IIDG1, pp. 570-82)

Another social impact is tearing down invisible barriers that prevent collaboration among different religious groups from happening. As one of the interviewees said, after so many years of getting to know each other and collaborating, a friendship is built, trust is generated, and great mutual knowledge and respect is reached. Everyone in the group has assumed all the principles, and they have been internalized. Under these circumstances, communities overcome these invisible barriers of ignorance and mistrust that place collaborating with other communities beyond their horizon and the absurdity that makes people see others more as a competition than as friends. Once these barriers are overcome, collaborations naturally flourish:

For instance, Sister Mercy [fictional name] suddenly receives a donation of perishable food, that cannot wait until Monday to the opening of the Food Bank to be delivered, then she calls de mosque, and tells them "Hey, I have this, can you distribute it today?", "Yes". Then they go to Sister Mercy, take it, and distributed it. (IIDG2, pp. 673-76)

\section{Conclusions}

Interreligious dialogue possesses several promising benefits and potential that can benefit its participants and the social contexts where it takes place, such as providing mutual understanding, gaining knowledge of one's own and the others' religion and beliefs, reducing prejudice and conflict, and improving social coexistence. Recent decades have witnessed a considerable increase in this practice worldwide and its spread to a greater diversity of groups, people, and countries. For more than a century, advocates have been defending and promoting interreligious dialogue; we can find writings from scientific and theological disciplines that reflect on how to carry out this dialogue to be fair, respectful, meaningful, appropriate, and fulfilling. However, we realized that there was scarce literature that delved into what conditions make this kind of dialogue achieve its stated goals. This study has contributed to filling such a gap by analyzing four IDG. The analysis has located and documented those conditions of interreligious dialogue that produce human agency, namely equality of differences, egalitarian dialogue, cultural intelligence, solidarity, and transformation. More concretely, we documented several forms of human agency produced by these groups: gaining self-confidence in harsh environments, developing advocacy and self-defense actions, widening knowledge of one's religion, knowing the other, mediating conflicts between ethnic and religious communities, and fostering multicultural social cohesion environments.

As Avci (2018, p. 4) highlighted, interreligious dialogue encompasses the most important feature of any dialogue: the self's intellectual and spiritual transformation. We indeed found different types of personal and social transformations due to the IDG' activities, including the reduction of prejudices and establishing new ideas for activities and collaborations between people who previously either did not know each other or who were estranged due to their biases.

The several social impacts of the IDG deserve further research. For instance, we have documented the reduction of extreme-right voting in a municipality where the interreligious dialogue group was very active, acting as an advocacy group in the face of intolerance and knitting social networks which led to a reduction in local votes for the extreme right to the extent that it disappeared from the local council. We think that further research into the links between the two phenomena is worthwhile. Moreover, through the literature review and the fieldwork on dialogues, we have observed that a multidisciplinary 
approach that includes social sciences and theology can be very advantageous. Even though this topic goes beyond the scope of this article, we think the dialogue between science and religion may achieve interesting and promising social impacts.

Author Contributions: Conceptualization, S.R.-P.; Methodology, M.Á.P.-R.; Validation, J.M.; Formal Analysis, R.C.-C., M.Á.P.-R.; Original Draft Preparation, R.C.-C.; Writing-Review \& Editing R.C.-C., M.Á.P.-R., S.R.-P.; Funding Acquisition, S.R.-P. All authors have read and agreed to the published version of the manuscript.

Funding: This research received funding from the consolidated research group on Sociological Theory and Research Impact in the Department of Sociology at the University of Barcelona for covering APCs, and from the Sociology Unit in the Department of Business Studies at the University of Girona for covering English editing.

Institutional Review Board Statement: The study was conducted according to the guidelines of the Declaration of Helsinki, and approved by the Ethics Committee of the Community of Researchers on Excellence for All (CREA) (protocol code 20210104 and approved on 12 January 2021).

Informed Consent Statement: Informed consent was obtained from all subjects involved in the study.

Data Availability Statement: The data presented in this study are available on request from the corresponding author. The data are not publicly available due to not consent from the participants for such publicity.

Acknowledgments: We would like to acknowledge all the interviewees that gave their time to do the interviews, and that altruistically provided information and their insight on the topic investigated.

Conflicts of Interest: The authors declare no conflict of interest.

\section{References}

Abu-Lughod, Lila. 2013. Do Muslim Women Need Saving? Cambridge: Harvard University Press.

Acosta, Emiliano. 2017. Diálogo interreligioso y reconocimiento a la luz del legado de la ilustración. Horizonte 15: 615-37. [CrossRef]

Aiello, Emilia, Claire Donovan, Elena Duque, Serena Fabrizio, Ramon Flecha, Paul Holm, Silvia Molina, Esther Oliver, and Emanuela Reale. 2021. Effective strategies that enhance the social impact of social sciences and humanities research. Evidence $\mathcal{E}$ Policy. A Journal of Research, Deabte and Practice 17: 131-46. [CrossRef]

Pastor Bonus. 1988. Apostolic Constitution Pastor Bonus John Paul II, Bishop Servant of the Servants of God for an Everlasting Memorial. Available online: https: / cutt.ly/71YM7rN (accessed on 12 December 2020).

Associació UNESCO per al Diàleg Inter-Religiós (AUDIR). n.d. Interreligious Dialogue Groups. Available online: https://audir.org/ grups-de-dialeg/ (accessed on 7 November 2020).

Astor, Avi, Mar Griera, and Mónica Cornejo. 2019. Religious governance in the Spanish city: Hands-on versus hands-off approaches to accommodating religious diversity in Barcelona and Madrid. Religion, State E Society 47: 390-404. [CrossRef]

Avci, Betül. 2018. Comparative Theology and Scriptural Reasoning: A Muslim's Approach to Interreligious Learning. Religions 9: 297. [CrossRef]

Azdajic, Dejan. 2019. Dialogue Beyond Belief: The Role of Participation in Religious Practices as the Meeting Point for Muslim Christian Encounter. Transformation 36: 196-209. [CrossRef]

Berger, Peter Ludwig. 2014. The Many Altars of Modernity: Toward a Paradigm for Religion in a Pluralist Age. Boston and Berlin: De Gruyter.

Burgués, Ana, Josep Luís Condom, José Antonio Rodríguez, and Rosa Maria Valls. 2016. El Diálogo Interreligioso como Herramienta para Desactivar el Prejuicio Racista. Revista Científica de Estudios sobre Interculturalidad 2: 86-111. [CrossRef]

Cerchiaro, Francesco. 2019. Fighting for What? Couples Communication, Parenting and Social Activism: The Case Study of a “Christian-Muslim" Families' Association in Brussles (Belgium). Religions 10: 270. [CrossRef]

Cherian, Joyson. 2019. An Interreligious Initiative for Peace and Harmony: A Christian Perspective. Transformation 36: 100-12. [CrossRef]

Cornille, Catherine, ed. 2013a. The Wiley-Blackwell Companion to Inter-Religious Dialogue. Sussex: Wiley-Blackwell.

Cornille, Catherine. 2013b. Conditions for Inter-Religious Dialogue. In The Wiley-Blackwell Companion to Inter-Religious Dialogue. Edited by Catherine Cornille. Sussex: Wiley-Blackwell, pp. 21-33.

De Botton, Lena, and Miguel Ángel Pulido-Rodríguez. 2013. Une Nouvelle Laïcité Multiculturelle. International and Multidisciplinary Journal of Social Sciences 2: 236-56. [CrossRef]

Dignitatis Humanae. 1965. Declaration on Religious Freedom Dignitatis Humanae on the Right of the person and of Communities to Social and Civil Freedom in Matters Religious Promulgated by His Holiness Pope Paul VI on 7 December 1965. Available online: https:/ / cutt.ly/w1YNCb6 (accessed on 12 December 2020). 
Nostra Aetate. 1965. Declaration on the Relation of the Church to Non-Christian Religions Nostra Aetate Proclaimed by His Holiness Pope Paul VI on 28 October 1965. Available online: https: / / cutt.ly / AlYMz94 (accessed on 12 December 2020).

Unitatis Redintegratio. 1964. Decree on Ecumenism Unitatis Redintegratio. Pope Paul VI on 21 November 1964. Available online: https:/ / cutt.ly/blYNb12 (accessed on 12 December 2020).

Orientalium Ecclesiarum. 1964. Decree on the Catholic Churches of the Eastern Rite Orientalium Ecclesiarum Solemnly Promulgated by His Holiness Pope Paul VI on 21 November 1964. Available online: https:/ / cutt.ly/rlYNwij (accessed on 12 December 2020).

Duemmler, Kerstin, and Alexander-Kenneth Nagel. 2013. Governing Religious Diversity: Top-down and bottom-up initiatives in Germany and Switzerland. Integrative Psychological and Behavioral Science 47: 265-83. [CrossRef]

Duina, Francesco, and Carson Dylan. 2020. Not so right after all? Making sense of the progressive rethoric of Europe's far-right parties. International Sociology 35: 3-21. [CrossRef]

Flecha, Ramon. 1999. Modern and Postmodern Racism in Europe. Dialogic Approach and Anti-Racist Pedagogies. Harvard Educational Review 69: 150-72. [CrossRef]

Flecha, Ramon. 2000. Sharing words. Theory and Practice of Dialogic Learning. Lanham: Rowman \& Littlefield. First published 1997.

Flecha, Ramon. 2014. Using mixed methods from a communicative orientation: Researching with grassroots roma. Journal of Mixed Methods Research 8: 245-54. [CrossRef]

Freire, Paulo. 1995. Pedagogía del Oprimido. Madrid: Siglo XXI. First published 1968.

Freire, Paulo. 1997. A la Sombra de Este Árbol. Barcelona: El Roure. First published 1995.

Giddens, Anthonny. 1990. La teoría Social Hoy. Madrid: Alianza Universidad. First published 1987.

Giddens, Anthonny. 2003. La Constitución de la Sociedad. Bases para la Teoría de la Estructuración. Buenos Aires: Amorrortu. First published 1984 .

Gramstrup, Louise Kølner. 2017. Searching for interreligious understanding: Complex engagements with sameness and difference in an American women's interfaith book group. Journal of Beliefs \& Values 38: 341-51. [CrossRef]

Gustafson, Hans. 2020. Defining the Academic Field of Interreligious Studies. Interreligious Studies and Intercultural Theology 4: 131-54. [CrossRef]

Habermas, Jürgen. 2010. Teoría de la Acción Comunicativa. Madrid: Trotta. First published 1981.

Hedges, Paul. 2019. The Secular Realm as Interfaith Space: Discourse and Practice in Contemporary Multicultural Nation-States. Religions 10: 498. [CrossRef]

Hustwit, Jeremy. 2016. Myself, Only Moreso. Conditions for the Possibility of Transreligious Theology. Open Theology 2: $236-41$. [CrossRef]

Khan, Issa, Mohammad Elius, Mohd Roslan Mohd Nor, Mohd Yakub Zuzkifli Bin Mohd yusoff, Kamaruzaman Noordin, and Fadillah Mansor. 2020. A Critical Appraisal of Interreligious Dialogue in Islam. SAGE Open 10: 1-10. [CrossRef]

Knauth, Thorsten, and Vieregge Dörthe. 2019. Researching religion-related dialog in schools -theoretical and methodological considerations. Religion \& Education 46: 20-39. [CrossRef]

Knitter, Paul Francis. 2013. Inter-Religious Dialogue and Social Action. In The Wiley-Blackwell Companion to Inter-Religious Dialogue. Edited by Catherine Cornille. Sussex: Wiley-Blackwell, pp. 133-38.

Küng, Hans. 1992. Proyecto de Una Ética Mundial. Madrid: Trotta. First published 1990.

Küng, Hans, Josef van Ess, Heinrich von Stieteneron, and Heinz Becbert. 1987. El Cristianismo y las Grandes Religiones: Hacia el Diálogo con el Islam, el Hinduismo y el Budismo. Madrid: Libros Europa.

Lopez de Aguileta, Garazi. 2019. Developing School relevant Language and Literacy Skills through Dialogic Literary Gatherings. International Journal of Educational Psychology 8: 51-71. [CrossRef]

Mezzetti, Giulia, and Roberta Ricucci. 2019. Political opportunity structures and the activism of first- and second-generation Muslims in two Italian cities. Religion, State $\mathcal{E}$ Society 47: 405-22. [CrossRef]

Michaelides, Pavlos. 2009. Interfaith dialogue in global pesrpective and the necessity of youth involvment. Asia Europe Journal 7: 449-62. [CrossRef]

Moin, Ahmed Azfar. 2017. Millennial Sovereignty, Total Religion, and Total Politics. History and Theory 56: 89-97. [CrossRef]

Mondéjar, Eduard, and Beatriz Villarejo. 2017. Las Tertulias Literarias Dialógicas como Herramienta Educativa en la Prevención del Conflicto Intercultural e Interreligioso. Revista Científica de Estudios sobre Interculturalidad 3: 86-100. [CrossRef]

Mortensen, Viggo. 2002. The Dialogue between Science and Religion and the Dialogue between People of Different Faiths: Areopagus Revisited. Zygon 37: 63-82. [CrossRef]

Panikkar, Raimon. 1999. The Intra-Religious Dialogue. New York: Paulist.

Gaudium et Spes. 1965. Pastoral Constitution on the Church in the Modern World Gaudium et Spes Promulgated by His Holiness, Pope Paul VI on 7 December 1965. Available online: https: / cutt.ly/slYMr88 (accessed on 12 December 2020).

Reale, Emanuela, Dragana Avramov, Kubra Canhial, Claire Donovan, Ramon Flecha, Poul Holm, Charles Larkin, Benedetto Lepori, Judith Mosoni-Fried, Esther Oliver, and et al. 2018. A review of literature on evaluating the scientific, social and political impact of social sciences and humanities research. Research Evaluation 27: 298-308. [CrossRef]

Said, Edward Wadie. 2002. Orientalismo. Madrid: Debate. First published 1978.

Sen, Amartya Kumar. 2007. India Contemporanea. Entre la Modernidad y la Tradición. Barcelona: Gedisa. First published 2005.

Sordé Martí, Teresa, Flecha Ramon, Rodríguez José Antonio, and Condom-Bosch José Luís. 2020. Qualitative Inquiry: A Key Element for Assessing the Social Impact of Research. Qualitative Inquiry 26: 948-54. [CrossRef] 
Swidler, Leonard. 2013. The History of Inter-Religious Dialogue. In The Wiley-Blackwell Companion to Inter-Religious Dialogue. Edited by Catherine Cornille. Sussex: Wiley-Blackwell, pp. 3-19.

Taylor, Charles, Amy Gutman, Steven Clark Rockefeller, Michael Walzer, and Susan Wolf. 2003. Multiculturalismo y la 'Politica del Reconocimiento'. Madrid: Fondo de Cultura Económica. First published 1992.

Todd, Nathan, Jaclyn Danielle Houston, and Rachael Suffrin. 2015. Applying affiliation social network analysis to understand interfaith groups. Psychosocial Intervention 24: 147-54. [CrossRef]

Torradeflot, Francesc, ed. 2002. Diálogo Entre Religiones. Textos Fundamentales. Madrid: Trotta.

Torras-Gómez, Elisabeth, Mengna Guo, and Mimar Ramis. 2019. Sociological Theory from Dialogic Democracy. International and Multidisciplinary Journal of Social Sciences 8: 216-34. [CrossRef]

Touraine, Alain. 1997. Podremos Vivir Juntos? Iguales y Diferentes. Madrid: PPU.

Ubani, Martin. 2018. What makes students feel authentic in an integrated RE classroom? Journal of Beliefs E Values 39: 169-81. [CrossRef]

United Religions Initiative (URI). 2020. United Relgions Initiative Charter. Available online: https://www.uri.org/who-we-are/PPP (accessed on 7 November 2020).

Vatican Pontifical Council for Interreligious Dialogue (VPCID). 1991. Reflection and Orientations on Interreligious Dialogue and the Proclamation of the Gospel of Jesus Christ. Available online: https:/ / www.vatican.va/roman_curia/pontifical_councils/interelg/ documents/rc_pc_interelg_doc_19051991_dialogue-and-proclamatio_en.html (accessed on 7 November 2020).

Wieviorka, Michel. 2007. The construction of what? In The Construction of Minority Identities in France and Britain. Edited by Gino Raymond and Tariq Modood. New York: Palgrave Macmillan, pp. 33-47. 